\title{
O nascimento de uma penitenciária: os primeiros presos da Casa de Prisão com Trabalho da Bahia (1860-1865) ${ }^{12}$
}

Cláudia Moraes Trindade 3

Neste artigo apresento um estudo sobre o perfil dos primeiros presos que ocuparam a Casa de Prisão com Trabalho, nome que recebeu a primeira penitenciária da Bahia, inaugurada no ano de 1861 na cidade de Salvador. Apresento um levantamento da população carcerária da cidade de Salvador visando situar o papel da Casa de Prisão na dinâmica do aparelho prisional da cidade no período de 1860 a 1865. Em seguida, variáveis como sexo, cor, idade, profissão, natureza do crime e sentença dos presos são analisadas. Finalizo com fragmentos de histórias de suas vidas.

Palavras-chave: Casa de Prisão com Trabalho - penitenciária - Bahia século XIX

\section{The birth of a penitentiary: the first prisoners at the Casa de Prisão com Trabalho} in Bahia (1860-1865).

In this article I discuss the profile of the first prisoners at the Casa de Prisão com Trabalho. A Penitentiary founded in 1861 in the city of Salvador, Bahia. I begin with a discussion of other prisons of Salvador in order to understand the role of the Casa de Prisão in the

\footnotetext{
${ }^{1 *}$ Artigo recebido e aprovado para publicação em abril de 2009.

$2^{*}$ Este artigo foi elaborado a partir do terceiro capítulo da dissertação de Mestrado intitulada "A Casa de Prisão com Trabalho da Bahia - 1833-1865", concluída em 2007 sob a orientação do Prof. Dr. João José Reis, a quem sou especialmente grata pelos comentários e indicação de fontes documentais e bibliográficas. Agradeço também as sugestões e críticas feitas pelos membros da linha de pesquisa Escravidão e Invenção da Liberdade, do Programa de Pós-Graduação em História da UFBA, e aos professores doutores Carlos Gabriel Guimarães e Magali Gouveia Engel, pareceristas da revista Tempo, que permitiram melhorar sensivelmente este texto. A pesquisa contou com o apoio do CNPq.

${ }^{3}$ Doutoranda em História pela Universidade Federal da Bahia/UFBA.
} 
dinamics of the local prisional sistem from 1860 until 1865. Then variables such as sex, color, age, ocupation, kind of crime and sentences are analised. I finish with fragments in the history of their lives.

Keywords: Prison-workhouse - penitentiary - Bahia-History 19th century

\section{La naissance d'une prison: les premiers prisonniers de la Casa de Prisão com Trabalho de Bahia (1860-1865).}

Dans cet article, je présente mon étude sur le profil des premiers priosonniers qui ont occupé la Casa de Prisão com Trabalho (Prison avec Travail), nom donné à la première maison d'arrêt de Bahia, fondée en 1861 dans la ville de Salvador. D’abord, je présente un bilan à propos de la population carcérale de Salvador en essayant de bien cerner le rôle joué par la Casa de Prisão dans la dynamique de l'appareil pénitentiaire de la ville pendant les années 1860-1865. Ensuite, j’analyse des questions concernant le profil des prisonniers (sexe, couleur, âge et profession), la nature des crimes et les sentences. À la fin de l'article, jétudie des fragments d'histoires de vie de ces détenus.

Mots-clés: Casa de Prisão com Trabalho - bagne - Bahia XIXe siècle

\section{Introdução}

O surgimento das instituições prisionais no início do século XIX tem sido alvo de muitos estudos nos anos recentes. A obra pioneira de Michel Foucault, Vigiar e Punir, publicada em 1975, suscitou os mais variados debates, contribuindo, desde então, para a reflexão sobre a prisão nas diferentes sociedades ao redor do mundo. Ninguém melhor do que Foucault revelou os mecanismos de vigilância e poder como símbolos da sociedade moderna. Entretanto, a preocupação de Foucault, segundo ele próprio declarou, não foi escrever a história da "instituição prisão, mas da prática do aprisionamento". ${ }^{4}$ Segundo Foucault, "a penalidade de encarceramento foi logo aceita como uma inovação a aperfeiçoar, mais do que a contestar", e assim ele buscou entender os motivos dessa "substituição apressada" e dessa "aceitação sem dificuldade" no início do século XIX."

\footnotetext{
${ }^{4}$ Mesa redonda em 20 de maio de 1978 com Michel Foucault, Carlo Ginzburg, Michele Perrot, Catherine Duprat, Maurice Agulhon, Jacques Ravel, Nicole Castan, François Ewald, Arlette Farge, Alexandre Fontana, Remi Gossez e Pascal Pasquino, In: Manoel Barros da Motta (org.), Michel Foucault: estratégia, poder e saber, Rio de Janeiro, 2003, p. 338. Esse texto foi publicado originalmente em Michelle Perrot (org.), L'impossible prison, Recherchers sur le système pénitentiaire au XIX stécle, Éd. du Seuil, col. L'Univers Historique, 1980, pp. 40-56.
}

${ }^{5}$ Michel Foucault, “A poeira e a nuvem”, In: Motta (org.), Michel Foucault, p. 324. 
É inegável a contribuição da obra de Foucault para o entendimento da adaptação da reforma prisional em várias partes do mundo e, no caso específico baiano, os modelos norte-americanos de Auburn e Pensilvânia, cujos mecanismos foram por ele estudados, estiveram presentes nos debates dos nossos reformadores, que passaram cerca de três décadas para decidir qual deles implantar na Bahia. Da mesma forma, destaco a importância das reflexões de Foucault sobre os discursos dos grandes pensadores da reforma prisional, como Charles Lucas, John Howard e Alex Toqueville, os quais também eram citados pelos estudiosos baianos. ${ }^{6}$ É sabida a influência europeia no projeto civilizatório oitocentista em escala global, mas, conforme sinalizou Frank Dikotter, "o surgimento da prisão na América Latina, Rússia, Japão, China ou Índia não pode ser interpretado como uma réplica tardia de um modelo Europeu, mas sim como uma apropriação local de ideias globais"?

Entretanto, quando o interesse do pesquisador passa a ser o cotidiano prisional, em que a ação dos prisioneiros é o centro de suas preocupações, os modelos europeus podem não ser suficientes. Para Dikotter, "muitos admiradores de Foucault tem aceitado acriticamente a visão do filósofo francês de que a prisão é uma criação perfeita do Estado moderno, enquanto que as evidências nos têm afastado cada vez mais da retórica oficial e das ideias grandiosas e demonstrado a realidade desordenada do encarceramento". Carlos Aguirre, em recente livro sobre os criminosos de Lima, assinala que o "pessimismo foucaultiano, que traduz o controle panóptico total," é contestado nos estudos que pretende focalizar as ações dos prisioneiros e os limites do Estado autoritário. Para o historiador peruano, até o mais despóticos dos regimes prisionais não consegue dominar completamente a determinação e a capacidade de resistir dos presos. ${ }^{9}$

\footnotetext{
${ }^{6}$ Sobre a reforma prisional baiana e a adaptação das ideias penitenciárias na Bahia, ver Cláudia Moraes Trindade, "A reforma prisional na Bahia oitocentista", Revista de História, n. 158 (1 semestre de 2008), pp. 157-198.

${ }^{7}$ Frank Dikotter, “The Prison in the World”, In: Frank Dikotter e Ian Brown (orgs.), Cultures of Confinement: A History of the Prison in Africa, Asia and Latin America. Ithaca, New York, Cornell University Press, 2007, p. 9. Carlos Aguirre, The Criminals of Lima and Their Worlds: The Prison Experience, 1850-1935, Durham, Duke University Press, 2005, p. 6.

${ }^{8}$ Frank Dikotter, “The Prison in the World”, In: Frank Dikotter e Ian Brown (orgs.), Cultures of Confinement: A History of the Prison in Africa, Asia and Latin America. Ithaca, New York, Cornell University Press, 2007, p. 9.

${ }^{9}$ Carlos Aguirre, The Criminals of Lima and Their Worlds: The Prison Experience, 1850-1935, Durham, Duke University Press, 2005, p.11.
} 
Ao invés do sistema penal transformar os presos em indivíduos dóceis e industriosos, as prisões têm produzido efeito contrário, pois se transformaram em arenas onde eles frequentemente reforçam suas identificações criminais. ${ }^{10}$ Trata-se da formação, dentro da prisão, de uma comunidade com regras próprias, de funcionamento complexo, envolvendo parcerias entre presos, guardas e outros funcionários. Não estou falando apenas do Brasil de hoje, que todos conhecem. Isso que Aguirre denomina de "ordem costumeira" prisional já existia na Bahia oitocentista, por exemplo. ${ }^{11}$

Neste artigo não discuto a concepção doutrinária nem o processo de implantação da penitenciária da Bahia, tampouco seu funcionamento, mas sim o perfil dos seus primeiros presos, aqueles que foram, literalmente, escolhidos para inaugurar a moderna instituição prisional, orgulho do projeto civilizador baiano. Fragmentos das histórias de suas vidas foram valorizados, revelando aspectos do cotidiano das pessoas comuns da Salvador oitocentista. A discussão aqui apresentada sugere que as particularidades de cada sociedade estão de algum modo refletidas no funcionamento das suas instituições prisionais e nas outras formas de punição que adotam.

No dia 31 de outubro de 1861, depois de um conturbado processo de construção, que durou cerca de três décadas, a Bahia inaugurou a sua primeira penitenciária que recebeu oficialmente o nome de Casa de Prisão com Trabalho. A instituição foi construída numa área pantanosa, concedida à Câmara Municipal pelo governo da província, que correspondia a "100 braças quadradas" localizada "na marinha fronteira ao Engenho da Conceição, pelos fundos da Capela dos Mares". ${ }^{12}$ Esse local pertencia a Freguesia da Nossa Senhora da Penha de França de Itapagipe, periferia da Cidade de Salvador. ${ }^{13}$

${ }^{10}$ Dikotter, “The Prison in the World", p. 10. Sobre "subculturas prisionais", ver Patricia O'Brien, "The Prison on the Continent, Europe 1865-1965, In: Norval Morris e David J. Rothman (orgs.), The Oxford History of the Prison, New York, Oxford University Press, 1995, p. 185.

${ }^{11}$ Sobre a ordem costumeira da prisão, ver Aguirre, The Criminals of Lima and Their Worlds: The Prison Experience, 1850-1935, Durham, Duke University Press, 2005, pp.143-154.

${ }^{12}$ Systema penitenciario, Relatório feito em nome da commissão encarregada, pelo Exellentissimo senhor Presidente da Provincia, de examinar as questões relativas à Casa de Prisão com Trabalho, da Bahia, Typographia de Galdino Joze Bizerra, e Companhia, 1847, p. 5, Biblioteca do Mosteiro de São Bento. Agradeço a João Reis pela localização deste documento.

${ }^{13}$ A partir de 1870, a freguesia da Nossa Senhora da Penha de França de Itapagipe foi desmembrada e o local da instituição passou a pertencer à Freguesia de Nossa Senhora dos Mares. Sobre as Freguesias do Arcebispado de São Salvador da Bahia, no período de 1549 a 1889, ver Cândido da 
Mesmo com parte das obras incompletas, a Casa de Prisão com Trabalho foi durante algum tempo, a menina dos olhos das autoridades da Bahia, ou, como bem observaram os presos em 1862, a instituição servia "como uma figa" aos governantes da província. ${ }^{14} \mathrm{~A}$ implantação da penitenciária fazia parte do projeto civilizador oitocentista e, como já mencionado, o Brasil acompanhava uma tendência mundial de modernização do sistema prisional, que teve início na Inglaterra e nos Estados Unidos no final do século XVIII. ${ }^{15}$ As execuções e as torturas em praças públicas, utilizadas para atemorizar a quem estivesse planejando novos crimes, foram, gradativamente, abandonadas. Entrava em cena a penalidade moderna que planejava privar o criminoso do seu bem maior - a sua liberdade - internando-o numa instituição construída especificamente para recuperá-lo, que recebeu o nome de penitenciária. $\mathrm{O}$ seu funcionamento era regido por normas que seriam aplicadas de acordo com o modelo penitenciário escolhido pelas autoridades, mas todos eles utilizavam elementos como o trabalho, a religião, a disciplina, o uso de uniformes e, sobretudo, o isolamento como métodos de punição e recuperação. Dessa forma, esperava-se criar um "novo homem”, que seria devolvido à sociedade com todos os atributos necessários à convivência social, principalmente para o trabalho. ${ }^{16}$ Foi com essas expectativas que os reformadores baianos implantaram a Casa de Prisão com Trabalho.

A Casa de Prisão com Trabalho foi planejada para atender aos sentenciados à pena de prisão com trabalho que, conforme o Código Criminal do Império do Brasil, só poderia ser aplicada aos homens livres e libertos. A Constituição de 1824 aboliu as penas corporais, "os açoites, a tortura, a marca de ferro quente, e todas as mais penas cruéis”. Essas proibições não se aplicaram todas elas aos escravos, pois com a substituição do Livro V das Ordenações Filipinas pelo Código Criminal do Império do Brasil, promulgado em 1830, os castigos corporais continuaram vigorando para eles. Para o homem livre a punição cor-

Costa e Silva, Os Segadores e a messe: o clero oitocentista na Bahia, Salvador, SCT, EDUFBA, 2000, pp. 67-73. Atualmente esta área é conhecida como Baixa do Fiscal e, no edifício em que funcionava a Casa de Prisão com Trabalho hoje é ocupado pelo Hospital de Tratamento e Custódia da Bahia.

${ }^{14}$ João Byspo da Neves para o Presidente da província, (03/1862), Arquivo Público do Estado da Bahia (doravante APEBa), Casa de Prisão, 1836-1868, maço 3082.

${ }^{15}$ Sobre os conceitos de civilização na Europa, ver Norbert Elias, O processo civilizador: uma história dos costumes, vol.1, Rio de Janeiro, Zahar, 1994, principalmente capítulo I.

${ }^{16}$ Sobre a Reforma prisional da Bahia e o projeto, ver Trindade, "A Reforma prisional na Bahia Oitocentista”. 
poral foi substituída pelas doutrinas penitenciárias, que tinham o objetivo de vigiar, disciplinar e recuperar o condenado. Essa dualidade no sistema criminal brasileiro foi uma realidade enquanto existiu a escravidão. ${ }^{17}$ De um modo geral, as penas estabelecidas pelo novo Código foram de morte, galés, prisão simples, prisão com trabalho, banimento, degredo, desterro para dentro do país, multa, suspensão ou perda de emprego, no caso de funcionários públicos, e açoites para os escravos. A pena de prisão com trabalho, aplicada para a maioria dos delitos, foi proibida para os escravos, medida que preservava os interesses senhoriais. ${ }^{18} \mathrm{E}$ importante esclarecer que a pena de prisão com trabalho era diferente da pena de galés ou trabalho forçado os quais eram, em geral, executados na prisão das galés do Arsenal da Marinha, onde os presos eram distribuídos nas obras públicas da cidade ou nos serviços internos do Arsenal. A pena de prisão com trabalho era cumprida dentro das penitenciárias em oficinas de trabalho - sapataria, marcenaria, funilaria, entre outras - e sob a orientação de um mestre de ofício. Vale ressaltar que as oficinas de trabalho da Casa de Prisão com Trabalho somente entraram em funcionamento no ano de 1865, o que significa falar que, durante os primeiros quatro anos de atividades, os presos foram privados de um dos principais elementos da nova doutrina prisional: o trabalho nas oficinas. ${ }^{19}$

\section{A população carcerária da cidade de Salvador.}

Segundo estimativa de Kátia Mattoso, no período de 1861 a 1865, a população de Salvador oscilou de 93.993 a 98.759 habitantes. ${ }^{20} \mathrm{O}$ censo de 1855 estimou

\footnotetext{
${ }^{17}$ Ibid.

${ }^{18}$ Artigo 60 "Si o réo for escravo, e incorrer em pena que não seja a capital ou de galés, será condemnado na de açoutes, e, depois de os soffrer, será entregue a seu senhor, que se obrigará a traze-lo com um ferro, pelo tempo e maneira que o juiz designar". O artigo 311 dizia que "A pena de galés temporarias será substituída pela de prisão com trabalho pelo mesmo tempo, logo que houver casas de correção nos lugares onde os reos estiverem cumprindo as sentenças" porém um Aviso de 9 de julho de 1850 logo tratou de informar que " esta substituição não pode ser feita aos escravos; porque, em vista do artigo 60, devem continuar a soffrer a pena de galés, visto como lhes não é applicavel a de prisão com trabalho", Araujo Filgueiras Junior, Código Criminal do Império do Brazil Annotado, Rio de Janeiro, Eduardo \& Henrique Laemmert, 1876, pp. 48-53 e 317.

${ }^{19}$ Sobre o trabalho prisional, ver Cláudia Moraes Trindade, A Casa de Prisão com Trabalho da Bahia, 1833-1865. Dissertação de Mestrado em História, Universidade Federal da Bahia, 2007, capítulo 2.

${ }^{20}$ Kátia M. de Queirós Mattoso, Bahia: a cidade do Salvador e seu mercado no século XIX, São Paulo, Hucitec, 1978, p. 138.
} 
a população da cidade em 86.984 pessoas e optei, quando possível, por utilizá-lo como parâmetro para a análise da população carcerária. ${ }^{21}$ Os habitantes de Salvador se misturavam constantemente com uma população flutuante que chegava por mar - marinheiros, negociantes, visitantes, escravos vendidos no mercado portuário e depois levados para outras localidades - e aquela oriunda do Recôncavo e dos sertões, que muitas vezes fugia das constantes secas em busca de meios de sobrevivência na cidade. Segundo Kátia Mattoso, as rotas de navegação do Recôncavo para a capital traziam, além das mercadorias, o habitante que, por sua vez, sentia-se "tão soteropolitano quanto o morador do Paço ou de Santana. Onde começava o Recôncavo, onde terminava a cidade?”.22 Os crimes cometidos no interior da província fizeram com que os seus habitantes tivessem uma representatividade significativa entre os presos da CPCT.

Com base na estatística de presos publicada nos relatórios dos presidentes da província foi possível estimar a população carcerária da cidade no período de 1861 a 1865. Esses números se referem aos presos que se encontravam detidos no final do ano, portanto não incluem a população carcerária flutuante, aquela detida no cotidiano das rondas policiais e liberada alguns dias depois.

Tabela 1 - População carcerária de Salvador - 1861-1865

\begin{tabular}{|c|c|c|c|c|c|c|c|c|c|c|c|c|}
\hline Instituições & 1861 & $\%$ & 1862 & $\%$ & 1863 & $\%$ & 1864 & $\%$ & 1865 & $\%$ & Média & $\%$ \\
\hline CPCT & 115 & 26,4 & 168 & 40,2 & 170 & 39 & 233 & 47,5 & 176 & 39,8 & 172 & 38,7 \\
\hline Cadeias $^{*}$ & 320 & 73,6 & 250 & 59,8 & 266 & 61 & 258 & 52,5 & 266 & 60,2 & 272 & 61,3 \\
\hline Total & 435 & 100 & 418 & 100 & 436 & 100 & 491 & 100 & 442 & 100 & 444 & 100 \\
\hline
\end{tabular}

Com exceção do ano de 1862, cujos números foram extraídos do mapa do carcereiro, os demais dados foram coletados nos relatórios de presidente da província. Fontes: Relatório dos presidentes da província anos de 1862 a 1866; "Mapa numérico de presos existente nas prisões da cadeia do Engenho da Conceição com declarações das classes e pena a que estão sentenciados”, APEBa, Mapa de presos recolhidos e Cadeias, 1861-1880, maço 6286. * No período de 1861 a 1864 considerar as Cadeia da Correção, do Barbalho e a prisão de galés do Arsenal da Marinha. Para o ano de 1865, excluir a do Barbalho, já extinta.

A penitenciária foi inaugurada com capacidade para duzentos presos, portanto a Tabela 1 também revela que neste período não houve superlotação, exce-

\footnotetext{
${ }^{21}$ Ana Amélia Vieira Nascimento, Dez Freguesias da Cidade de Salvador, Salvador, Fundação Cultural do Estado da Bahia, 1986.

${ }^{22}$ Mattoso, Idem, p. 179.
} 
tuando-se o ano de 1864, situação provocada, provavelmente, pela desativação da Cadeia do Barbalho, cujos presos foram divididos entre a CPCT e a Casa de Correção. ${ }^{23}$ Para termos uma ideia de como era feita a distribuição desses presos, podemos utilizar como exemplo o ano de 1863. A Tabela 1 informa que no final desse ano, a população carcerária era de 436 pessoas, sendo que 170 estavam na CPCT, 110 na Casa de Correção, 60 na Cadeia do Barbalho e 96 na prisão das galés do Arsenal da Marinha. Desses últimos, 27 estavam direcionados para serviços públicos nos quartéis e fortalezas da cidade. ${ }^{24}$

Ainda considerando o ano de 1863, dos 436 presos, 296 eram sentenciados de justiça, sendo que 170 estavam na CPCT e o restante nas outras cadeias, indicando que o quadro prisional da penitenciária estava formado apenas por sentenciados, já que era esse o número total de presos em dezembro daquele ano. ${ }^{25}$ Esse perfil pode indicar a preocupação das autoridades em manter os objetivos da instituição. Quanto aos outros presos, que cumpriam suas sentenças nas cadeias comuns, só lhes restava continuar a mercê das velhas práticas inconstitucionais como, por exemplo, dividindo a mesma cela com vários companheiros, além de serem privados dos supostos benefícios da prisão-modelo da Bahia. ${ }^{26}$

\footnotetext{
${ }^{23}$ Sobre a desativação da cadeia civil do Barbalho, ver Relatório que o excelentíssimo senhor desembargador Antonio Joaquim da Silva Gomes, (....) entregou à administração da provincia ao seu sucessor o senhor doutor Luis Antonio Barboza d' Almeida em 5 de novembro de 1864, Bahia, Typografia Poggeti - De Tourinho, Dias \& C., 1864, p. 11. A Casa de Correção também era chamada de "Cadeia da Correção" ou "Correção", sendo estas últimas denominações as mais utilizadas na documentação. A Bahia foi a única província do Império do Brasil a chamar uma cadeia comum de "Casa de Correção". De um modo geral, no Brasil oitocentista, essa nomenclatura era empregada para denominar as primeiras penitenciárias.

${ }^{24}$ Relatório com que o excelentíssimo senhor conselheiro Antonio Coelho de Sá e Albuquerque, presidente da província, passou interinamente a administração da mesma ao Exm. senhor conselheiro Manuel Maria do Amaral, vice-presidente, em 15 de dezembro de 1863, p. 9.

${ }^{25}$ Para o total de sentenciados presos em Salvador, ver Ibid., p. 9. Para o tipo de sentença dos 170 presos da CPCT, ver "Mapa numérico de presos existente nas prisões da cadeia do Engenho da Conceição com declarações das classes e pena a que estão sentenciados", APEBa, Mapa de presos recolhidos e Cadeias, 1861-1880, maço 6286. Essa relação informa que todos os presos eram sentenciados de justiça.

${ }^{26}$ Durante a segunda metade do século XIX, a Cadeia da Correção continuou, em número cada vez mais significativo, a dividir os sentenciados com a Casa de Prisão com Trabalho. A partir de 1865, a Cadeia da Correção também passou a abrigar as mulheres sentenciadas da província.
} 
Tabela 2 - Homens e mulheres presos em Salvador

\begin{tabular}{|c|c|c|c|c|c|c|c|c|c|c|}
\hline & 1861 & $\%$ & 1862 & $\%$ & 1863 & $\%$ & 1864 & $\%$ & 1865 & $\%$ \\
\hline Homens & 394 & 90,6 & 371 & 88,8 & 398 & 91,3 & 451 & 91,9 & 398 & 90,0 \\
\hline Mulheres & 41 & 9,4 & 47 & 11,2 & 38 & 8,7 & 40 & 8,1 & 44 & 10,0 \\
\hline Total & 435 & 100 & 418 & 100 & 436 & 100 & 491 & 100 & 442 & $100 \%$ \\
\hline
\end{tabular}

Fonte: Relatórios de presidente de províncias dos anos de 1862 a 1866.

A Tabela 2 informa a baixa incidência de mulheres na população carcerária da cidade. Considerando os números acima, veremos que a média de presas, no período de 1861 e 1865 , foi de 9,45\%. Número bastante reduzido se o compararmos com os dados fornecidos pelo censo de 1855, onde consta que as que as mulheres eram a maioria da população, representando $53,31 \%$ dos habitantes. ${ }^{27}$ No recenseamento do ano de 1872 essa proporção caiu, mas continuou significativa com uma representatividade de $47 \% .^{28}$

Num estudo feito por Holloway, referente ao Rio de Janeiro, entre 1862 e 1865 , as mulheres também apareceram com pouca representatividade. Conforme o autor, das 7.290 prisões arroladas de pessoas livres e escravas apenas 3,9\% foram de mulheres. ${ }^{29} \mathrm{O}$ censo de 1872 indicou que, também, no Rio de Janeiro, as mulheres tinham grande participação na composição da população compreendendo $42 \%$ dos habitantes. ${ }^{30}$ Ao que parece, a baixa participação feminina na criminalidade foi uma tendência mundial. Lucia Zedner, em seu estudo sobre prisões femininas, observou que na primeira metade do século XIX as mulheres constituíam uma pequena minoria da população das prisões. Na Inglaterra $20 \%$, na França de 14 a 20\% e nos Estados Unidos apenas 4 a 19\% eram de mulheres. ${ }^{31}$ Como podemos ver, a incidência criminal feminina na Bahia era maior que no Rio de Janeiro, porém ficando abaixo de países como a Inglaterra e França.

\footnotetext{
${ }^{27}$ Nascimento, Dez Freguesias da Cidade de Salvador, p. 94.

${ }^{28}$ Os recenseamentos gerais dos séculos XIX: 1872-1890, São Paulo, Centro Brasileiro de Análise e Planejamento (CEBRAP), CD-ROOM; Sobre as mulheres e a criminalidade em Salvador, ver Marília M. Pinto Muricy, Criminalidade na Bahia no século XIX, Dissertação de Mestrado em Ciências Sociais, Universidade Federal da Bahia, 1973.

${ }^{29}$ Holloway, Polícia, p. 195.

${ }^{30}$ CEBRAP, Os recenseamentos.

${ }^{31}$ Lucia Zedner, "Wayward Sisters: The Prison for Women”, In: Morris e Rothman (orgs.), The Oxford History of the Prison, p. 297.
} 


\section{O perfil dos primeiros presos da penitenciária}

Esse perfil é apresentando com base na coleta de informações de 111 presos que deram entrada na CPCT no período de 1861 a 1865 . Os documentos utilizados foram as guias de assentamento que acompanhavam o preso por ocasião de sua entrada na CPCT, fosse tal entrada por transferência de outras cadeias, ou por remessa da repartição de polícia. Algumas dessas guias trazem informações como nome, filiação, estado civil, "qualidade" (cor e origem), condição jurídica (escravo, liberto ou livre), nacionalidade, profissão, estatura, sinais particulares, a ordem da autoridade que o mandou recolher, motivo da prisão, data da entrada, sentença e observações sobre apelação e comutação de penas etc. ${ }^{32}$ Infelizmente, muitas dessas guias não contemplam todos os quesitos mencionados, mas fornecem o nome do preso e alguma outra particularidade que me permitiu rastreá-lo em outras cadeias antes da sua remoção para a CPCT. Os ofícios de chefes de polícia foram de suma importância na localização desses presos. A dificuldade de localizar registros mais completos na documentação da CPCT pode também estar relacionada ao fato de a pesquisa estar centrada no período inicial da instituição.

Desse grupo de 111 pessoas, as mulheres eram em número de 16 ou 14,4\%. Um pouco acima da média da cidade, que há pouco vimos ser de 9,45\%. Dos 111 presos, 61 tiveram a idade declarada, revelando que 38 presos tinham entre 20 e 35 anos, 22 tinham entre 40 e 55 anos e um preso com idade de 80 anos. ${ }^{33}$ Esse último, de idade bastante avançada, era um africano chamado Adrião Bornú, preto, casado e declarado como "sem profissão". A sua condenação foi de prisão perpétua com trabalho, por crime de morte. $\mathrm{O}$ juiz da $3^{\circ}$ vara, atendendo ao que previa o Código Criminal, remeteu-o para a CPCT, em 23 de novembro de 1863, a fim de que ele cumprisse pena de prisão perpétua com trabalho, em substituição à de galés perpétua, devido ao fato do mesmo ser maior de 60 anos. ${ }^{34}$

\footnotetext{
${ }^{32}$ Guias de transferência de presos, APEBa, Polícia, Casa de Prisão, (1861-1886), maço 5942.

33 "Cento e setenta e dois presos que se achão actualmente recolhidos nesta Casa", (29/09/1865), APEBa, Mapa de Presos, 1864-1869, maço 6287. Guias de transferência de presos.

34 "Cento e setenta e dois presos que se achão actualmente recolhidos nesta Casa". Sobre a pena de galés para maiores de 60 anos o artigo 45 do Código Criminal determinava que "Quando o condemnado a galés, estando no cumprimento da pena, chegar à idade de sessenta anos, ser-lhe-ha esta substituida pela de prisão com trabalho por outro tanto tempo quanto ainda lhe faltar para cumprir". Daí o termo prisão perpétua com trabalho, Filgueiras Junior, Código Criminal do Império do Brazil Annotado, p. 33.
} 
O segundo nome de Adrião indicava a sua nação africana, como era chamada a reordenação no Brasil dos grupos étnicos africanos. ${ }^{35} \mathrm{~A}$ presença da nação Borno na Bahia foi muito tímida, representando 1,5\% da população africana no ano de 1835. João Reis localizou alguns africanos dessa nação entre os revoltosos da Rebelião Malê em 1835. ${ }^{36}$ Possivelmente, Adrião era muçulmano. Sobre seu crime não consegui informações. Provavelmente, estava cumprindo a pena de galés perpétua no Arsenal da Marinha pela acusação de algum crime cometido na juventude e, como, só a partir de 1861, a Bahia passou a dispor de uma instituição própria para o cumprimento da pena com trabalho o Juiz teria aplicado o artigo 45 do Código Criminal.

Quanto às 16 mulheres, apenas uma teve a idade declarada. Trata-se da africana liberta Constança Pessoa da Silva, nação nagô, de 48 anos, cuja profissão foi definida como "negócios", o que significa que ela deveria ser uma das muitas africanas libertas que viviam "do ganho" para garantir o sustento. ${ }^{37}$ Constança foi julgada em 22 de outubro de 1865, enquadrada no artigo 192 do código criminal, e condenada a dois anos de prisão com trabalho. Tal artigo se referia ao crime de homicídio, em circunstâncias agravantes, que previa a pena de grau mínimo de 20 anos de prisão com trabalho, o grau médio era equivalente a galés perpétua, não aplicada às mulheres, e o grau máximo correspondia à pena de morte. Nesse caso, a pena de dois anos, informada na guia de assentamento de Constança,

\footnotetext{
${ }^{35}$ Conforme Luís Nicolau Parés, a origem dos nomes de nação "não é homogênea e pode referir-se a portos de embarque, reinos, etnias, ilhas ou cidades. Eles foram utilizados pelos traficantes e senhores de escravos, servindo aos seus interesses de classificação administrativa e controle. Em muitos casos, os portos ou a área de embarque parece ter sido um dos critérios prioritários na elaboração dessas categorias (Mina, Angola, Cabo Verde, São Thomé etc.). Tratava-se, portanto, de denominações que não correspondiam necessariamente às autodenominações étnicas utilizadas pelos africanos em suas regiões de origem"; Luis Nicolau Parés, A Formação do Candomblé: História e Ritual da Nação Jeje na Bahia, Campinas, Editora Unicamp, 2006, p. 24-25. Sobre nações africanas, ver também Maria Inês Cortês de Oliveira, "Viver e morrer no meio dos seus", Revista USP, n. 28 (1995-1996), p. 174-193 e da mesma autora, "Quem eram os negros da Guiné? A origem dos africanos na Bahia”, Estudos Afro-Asiáticos, n. 19-20 (1999).

${ }^{36}$ João José Reis, Rebelião escrava no Brasil: a história do levante dos Malês em 1835, Edição Revista e Ampliada, São Paulo, Companhia das Letras, 2003, pp. 174 e 327.

${ }^{37}$ As mulheres negras escravas, livres e libertas trabalhavam no pequeno comércio da cidade através do sistema de ganho. As primeiras eram obrigadas a pagar aos seus senhores uma quantia préestabelecida, enquanto que as outras podiam desfrutar integralmente do produto de seu trabalho. Sobre as ganhadeiras, ver Cecília Moreira Soares, "As ganhadeiras: mulher e resistência negra em Salvador no século XIX”, Afro-Ásia, no 17 (1996), pp. 57-61.
} 
pode ter sido um erro do escrivão que se esqueceu da casa da unidade. Constança apelou da sentença, mas seu recurso foi julgado improcedente pelo Tribunal da Relação em 24 de Março de 1866.

Ao contrário das penitenciárias da Corte e de São Paulo, a CPCT não tinha menores de idade no seu quadro de prisioneiros. Gláucia Pessoa encontrou, na penitenciária da Corte, menores entre 14 e 19 anos, que compreendiam 14\% do total do quadro prisional daquela instituição no ano de 1855 (cinco anos após a inauguração). Para São Paulo, Fernando Salla informa que, no ano de 1862, havia três menores na penitenciaria. ${ }^{38}$ Um deles, um escravo de nome José, que teria sido "condenado pelo Jury da cidade de Campinas, a ficar detido nesta Penitenciária [de São Paulo] até completar a idade de quinze anos". ${ }^{39}$

Salvador, localizei menores nas cadeias comuns como, por exemplo, na cadeia da Correção. Ali existiu o menor Antonio Marcelino dos Santos, pardo com quinze anos de idade, que foi preso na Praça do Palácio enquanto apedrejava um pobre homem "idiota". Antonio foi levado para cadeia de Correção em 15 de janeiro de 1862 por ordem do Chefe de polícia. ${ }^{40}$ Outro caso foi do menor Manoel, que se encontrava internado na mesma cadeia de Correção, onde adoeceu e acabou morrendo de "bexigas" no Hospital da Caridade em 3 de fevereiro de 1862. O administrador da cadeia comunicou ao chefe de polícia sobre a morte de Manoel, ocasião em que aproveitou para devolver um ofício que deveria ter acompanhado o menor até a presença do Juiz de Órfãos. ${ }^{41}$ Como podemos ver, este é mais um indício de que cada província adaptou a instituição penitenciária de acordo com a sua realidade. Para Ricardo Salvatore, esse regionalismo foi um dos fatores que contribuiu para o que ele acredita ter sido o fracasso da reforma penitenciária no Brasil durante o período Imperial. ${ }^{42}$

${ }^{38}$ Gláucia Tomaz de Aquino Pessoa, Trabalho e resistência na penitenciária da Corte, 1850-1876, Dissertação de Mestrado, Universidade Federal Fluminense, 2000, p. 170; Fernando Salla, As prisões de São Paulo: 1822-1940, São Paulo, Anablume, 1999, p. 97.

${ }^{39}$ Fernando Salla, As prisões de São Paulo: 1822-1940, São Paulo, Anablume, 1999, p. 92.

${ }^{40}$ Alferes Pedro José Vieira para o chefe de Polícia, (15/02/1862), APEBa, Relação de Presos, 1862 1867, maço 6272.

${ }^{41}$ Administrador da Cadeia da Correção para o chefe de polícia, (08/02/1862), APEBa, Relação de Presos, 1862-1867, maço 6272.

${ }^{42}$ Ricardo Salvatore, "Penitentiaries, Visions of Class, and Export Economies", In: Ricardo Salvatore e Carlos Aguirre (orgs.), The Birth of the Penitentiary in Latin America: Essays on Criminology, Prison Reform, and Social Control, 1830-1940, Austin, University of Texas Press, 1996, p. 200. 
Tabela 3 - Motivo da prisão dos 111 sentenciados - 1861-1865

\begin{tabular}{|l|c|c|c|}
\hline Crimes & Mulheres & Homens & Total \\
\hline Morte & 14 & 42 & 56 \\
\hline Furto & 0 & 10 & 10 \\
\hline Ferimentos Graves & 0 & 8 & 8 \\
\hline Estelionato & 0 & 6 & 6 \\
\hline Roubo & 1 & 3 & 4 \\
\hline Tentativa de morte & 0 & 2 & 2 \\
\hline Deserção & 0 & 2 & 2 \\
\hline Ofensas físicas e graves & 0 & 1 & 1 \\
\hline Resistência & 0 & 1 & 1 \\
\hline Redução de pessoa livre a escravidão & 0 & 1 & 1 \\
\hline Não Informa & 1 & 19 & 20 \\
\hline Total & 16 & 95 & 111 \\
\hline
\end{tabular}

Fonte: Guias de transferência de presos para a CPCT, APEBa, Casa de Prisão, 1861-1886, maço 5942; "Cento e setenta e dois presos que se achão actualmente recolhidos nesta Cas"; "Relação de presos da cadeia da correção", APEBa, Cadeias, 1857-1861, maço 6271.

O motivo da prisão foi apurado em 91 dos casos, conforme discriminado na Tabela 3. Entre as mulheres essa condenação foi bastante representativa. Das 16 mulheres, 14 foram condenadas por crime de morte, uma por roubo e quanto à outra não tenho informação. Entre aos homens, 42 foram sentenciados por crime de morte, 10 por furto, oito por ferimentos graves, seis por estelionato, três por roubo, dois por deserção, dois por tentativa de morte, um por resistência, um por ofensas físicas e graves e um por ter reduzido pessoa livre à escravidão. ${ }^{43}$

Nota-se que o crime de morte foi o mais comum, representando um total de $70 \%$ dos casos. Essa estatística seria típica de uma sociedade pré-capitalista, onde crimes violentos envolvendo defesa da honra sobrepujavam aqueles contra a propriedade. Segundo Aufderheide, com a transição da sociedade de ordens para a de classe, nos países europeus e nos Estados Unidos, a proporção entre os tipos

${ }^{43} \mathrm{O}$ crime de "reduzir pessoa livre a escravidão" pode ter se intensificado com o aumento do contrabando de africanos após a proibição do tráfico em 1831. Conforme Sidney Chalhoub "milhares e milhares de africanos, introduzidos ilegalmente no país, foram reduzidos à escravidão no período, e 'reduzir pessoa livre a escravidão' era crime previsto no código criminal do Império". Sidney Chalhoub, "Diálogos políticos em Machado de Assis", In: Leonardo Affonso de Miranda Pereira (org.), A História contada, Rio de Janeiro, Nova Fronteira, 1998, p. 104. 
de crime também mudaram. "Crimes contra a propriedade e sem vítima aumentaram, enquanto que violência pessoal, crimes morais e religiosos, tenderam a diminuir." ${ }^{44}$ Estudando o Brasil, a autora analisou a população carcerária de algumas de suas principais prisões na década de 1830, ou seja, após a instauração do Código Criminal, e constatou existir entre os presos um maior número de homens livres sentenciados por crime contra a propriedade. Segundo ela, os crimes de violência pessoal e contra a honra, principais causas das prisões no período anterior diminuíram pelo menos no caso de condenação. Uma das fontes da autora foi um relatório elaborado pelo Ministério da Justiça, para o período de 1836-1839, onde os crimes contra a propriedade correspondiam à metade das ocorrências nas duas principais prisões do Rio de Janeiro. Os crimes de violência pessoal não chegaram a 30\%. Já na penitenciária baiana, a maioria dos crimes, conforme mostra a Tabela 4, foram de violência pessoal, o que indica que o perfil dos crimes não se alterou com a modernização do sistema prisional. Em outras palavras, a Bahia permaneceu com uma característica pré-capitalista de criminalidade.

Entre as mulheres condenadas por crime de morte estava a escrava crioula Maria Benedita, sentenciada à prisão perpétua. Maria veio remetida da cadeia da Correção em 4 de outubro de 1862. A data do seu julgamento consta como ignorada. Em 1863, foi internada às pressas para ser "curada de um ataque que teve, e que denotava perigo de vida". Após um mês de internamento, Maria deu à luz uma menina que recebeu o nome de Joana. Mãe e filha ficaram internadas por mais sete meses e no dia 10 de julho de 1864 Maria recebeu alta e retornou para a CPCT. Três dias depois, a irmã superiora remeteu a pequena Joana para ficar ao lado de mãe. $\mathrm{O}$ administrador mostrou-se indignado com o comportamento da irmã superiora e não hesitou em informar ao chefe de polícia o seu repúdio a permanência daquela criança na prisão, pois,

[...] sendo aquelle Estabelecimento [a Santa Casa de Misericórdia] um dos asylos dos infelizes, e onde se recebem expostos, deveria tomar o cuidado da referida criança, muito mais quando se sabe que por aqui não pode ella ter o desvello que merece; sujeitando-se quasi só a amamentação da mãe. ${ }^{46}$

\footnotetext{
${ }^{44}$ Patrícia Aufderheide, Order and Violence: Social Deviance and Social Control in Brazil, 17801840, Tese de Doutorado, University of Minnesota, 1976, p. 6.

${ }^{45}$ Ibid., 324.

${ }^{46}$ Administrador da CPCT para o chefe de polícia, (13/07/1864), APEBa, Mapa de Presos, maço 6273.
} 
Levando em conta que Maria foi removida da Cadeia da Correção para a CPCT em 4 de outubro de 1862, podemos supor que ela engravidou na prisão e a possibilidade do pai da criança ser algum preso ou funcionário não é remota. Infelizmente não tive mais notícias sobre esse caso.

No ano de 1864, Maria estava novamente às voltas com questões de maternidade. Através de uma petição, ela informou ao chefe de polícia que tinha um filho de 8 anos chamado Arcelino Eleutherio Ceveriano. Ela teria entregado a criança para um tal Manoel Teixeira, morador da Lapa, "apretesto de o batizar e ensinarlhe seu ofício”. Era comum naquela época a participação de mestres de ofício na educação profissional das crianças, com a aquiescência dos pais. Também eram corriqueiras as denúncias de maus tratos, praticados contra esses menores pelos seus mestres. ${ }^{47}$ Segundo Maria, tal homem não cumpriu com o combinado e, ao mandar um portador saber informações sobre seu filho, Manoel negou que tivesse feito qualquer acordo com ela e tampouco sabia do paradeiro do menino. Maria pleiteou ao chefe de polícia que este intimasse Manoel e o colocasse frente a frente com ela a fim de que ele devolvesse ou revelasse o paradeiro do seu filho. O apelo de Maria foi atendido pelo chefe de polícia que, em 3 de agosto de 1864, mandou o subdelegado da Freguesia de São Pedro intimar Manoel a comparecer à Repartição. ${ }^{48} \mathrm{O}$ fato de estar presa não a impediu de lutar pelos seus direitos de mãe. Não tive mais notícias de Maria.

Depois do crime de morte, o de maior incidência entre os homens foi o de furto. Nesse crime se envolveu o crioulo Manoel Passos Ramos, solteiro de 46 anos, cuja ocupação foi declarada como servente. Em 1863, Manoel foi condenado a cumprir a pena de sessenta dias de prisão com trabalho por "furto de linguiças" e também condenado a pagar uma multa de trinta mil réis por ter "quebrado o termo de bem viver". ${ }^{49}$ Segundo Walter Fraga, muitas pessoas pobres

\footnotetext{
${ }^{47}$ Sobre o assunto, ver Alfredo Eurico Rodrigues Matta, “Casa Pia Colégio de Órfãos de São Joaquim: de recolhido a assalariado”, Dissertação de Mestrado, Universidade Federal da Bahia, 1996; Walter Fraga Filho, Mendigos, moleques e vadios na Bahia do século XIX, Salvador, EDUFBA, 1999.

${ }^{48}$ Maria Benedita para o chefe de polícia, (1864), APEBa, Mapa de Presos, 1861-1869, maço 6287.

${ }^{49}$ Guias de transferência de presos, $\mathrm{O} \$ 2$ do artigo 12 do Código de Processo Criminal de 1832 dizia que os juízes de paz teriam que "obrigar a assignar termo de bem viver os vadios, mendigos, bebados por habito, aos turbulentos que por palavras ou açoes que offendem os bons costumes, a tranquilidade publica, e a paz das famílias". Após assinarem o termo, essas pessoas deveriam agir dentro dos padrões esperados, e a quebra do "contrato" resultava em multas e prisão. A partir de 1841, com a reforma da justiça, o "termo de bem viver" passou a ser de responsabilidade das auto-
} 
eram detidas por roubarem gêneros de primeira necessidade, como o caso, citado pelo autor, do crioulo José Manuel da Conceição, ex-corneta de um batalhão do Exército que, na ocasião em que foi preso, no ano de 1860, confessou que roubava para "matar a fome.".50 Diante da pobreza da população não é difícil de imaginar que Manoel Passos estivesse passando privações, razão que o teria levado a furtar as linguiças. O motivo da condenação de Manoel foi o mais banal que encontrei entre os 111 presos analisados.

O "termo de bem viver" era mais um meio de controle de que se valiam as autoridades policiais para enquadrar a camada livre e pobre dentro dos padrões esperados, obrigando-os muitas vezes a procurar uma ocupação que não fosse considerada vadiagem..$^{51}$ Não sei por qual motivo obrigaram Manoel a assinar o "termo". É provável que ele fosse mais um dos muitos considerados vadios, por andar pelas ruas sem ter nem mesmo o que comer. Talvez tivesse sido chamado a assinar o "termo", em 1861, quando se encontrava preso na Cadeia de Correção e, por ordem de Henriques, o chefe de polícia, foi colocado em liberdade. ${ }^{52}$ No dia 2 de julho de 1862, o chefe de polícia remeteu Manoel para a Casa de Prisão com Trabalho, a fim de que este fosse "empregado" no serviço de servente. ${ }^{53}$ Pelo visto Manoel não gostou da ideia, uma vez que fugiu. Em novembro daquele mesmo ano, acabou caindo outra vez nas malhas do chefe de polícia que o encaminhou novamente para a CPCT, dizendo ao carcereiro que empregasse "no serviço para que for afeto, o vagabundo Manoel dos Passos Ramos, que d’ahi fugira

ridades policiais, na figura do Chefe de Polícia. Código do Processo Criminal de 1832, Capítulo II, Art. 12, In: Araujo Filgueiras Junior, Código do Processo do Império do Brasil e todas as mais leis que posteriormente forão promulgadas, e bem assim todos os decretos expedidos pelo poder executivo, relativamente as mesmas Leis..., Tomo I, Rio de Janeiro, Eduardo \& Laemmert, 1874, p. 15; Lei de 3 de Dezembro de 1841, Reformando o Código do Processo Criminal, Filgueiras Junior, Código do Processo do Império do Brasil..., tomo II, p. 23.

${ }^{50}$ Ibid., p.89.

${ }^{51}$ Segundo Walter Fraga, "no contexto de uma sociedade escravista, em que o controle dos senhores no máximo abrangia escravos e agregados, a criminalização da vadiagem se constituiu em poderoso recurso de controle extraeconômico utilizado pelas autoridades para constranger os homens pobres e livres ao trabalho", Walter Fraga Filho, Mendigos, moleques e vadios na Bahia do século XIX, Salvador, EDUFBA, 1999, p. 77.

${ }^{52}$ Chefe de polícia para o carcereiro da cadeia da correção, (26/11/1861), APEBa, Polícia, Correspondência expedida, 1861-1862, maço 5745 .

${ }^{53}$ Carcereiro da cadeia da correção para o administrador da CPCT, (02/07/1862), APEBa, Polícia, Casa de Prisão, 1861-1862, maço 5925. 
ultimamente".54 Talvez a rejeição ao trabalho de servente na penitenciária tenha sido o motivo que levou Manoel à quebra do "termo de bem viver".

A Tabela 3 também aponta para três casos de roubo entre os homens. Um deles foi o do crioulo liberto Tiburcio Rodrigues de Oliveira, 26 anos, solteiro, pedreiro. O funcionário que preencheu sua guia o descreveu como um homem de "estatura alta, corpo regular, cabeça pontuda, rosto comprido, testa alta, nariz afilado, boca regular, labios grossos, dentes perfeitos, olhos pretos, barba nenhuma".55 Esse tipo de descrição, conhecida como "sinais característicos e particulares", era uma prática policial ainda do antigo regime prisional, que visava assim identificar o prisioneiro principalmente em caso de fuga ou reincidência.$^{56}$ Desde o início do século XIX, os "sinais característicos" eram utilizados nos anúncios de fuga de escravos, nos jornais, com o intuito de auxiliar na identificação do fugitivo. Esses anúncios, de certa forma, anteciparam as práticas de identificação policial moderna. Ao se reportar à França, nos anos de 1846-1847, Michelle Perrot observou que os "sinais característicos" eram utilizados pela polícia francesa para controle dos presos reincidentes. O presidente de um tribunal teria sugerido "tomar à sua entrada os sinais físicos das pessoas nuas [....] pois frequentemente existem marcas que os próprios acusados não conhecem e assim não podem tentar apagar.".57

Não localizei qual foi o roubo atribuído a Tiburcio, apenas que em 26 de abril de 1863, ele foi preso como escravo fugido e ladrão, e foi mandado para a Cadeia de Correção por ordem do subdelegado da Freguesia de Sant'Anna. Em 14 de dezembro de 1864, foi indiciado por crime de roubo e em 8 de agosto de 1865, julgado e condenado pelo júri da capital à pena de " 400 açoites e a trazer um ferro de cravo no pescoço por dois anos como escravo de Manoel Rodrigues de Oliveira".58 Tiburcio apelou da sentença e, em 4 de novembro de 1865, foi reconhecido liberto

\footnotetext{
${ }^{54}$ Chefe de Polícia para o carcereiro da CPCT, (14/11/1862), APEBa, Polícia, Casa de Prisão, 18611862, maço 5925.

${ }^{55}$ Guias de transferência de presos da cadeia da correção para a CPCT, (28/12/1865), APEBa, Casa de Prisão, 1861-1886, maço 5942.

${ }^{56}$ É importante lembrar que os sinais característicos utilizados no período de nossa pesquisa nada tinham a ver com as teorias racialistas do final do século XIX.

${ }^{57}$ Michelle Perrot, Os Excluídos da História: operários, mulheres e prisioneiros, São Paulo: Paz e Terra, 2001, p. 285.

${ }^{58}$ A "gargalheira - armação de ferro em forma de cruz - em torno do pescoço, método com que se costumava punir escravos que fugiam". Reis, Rebelião escrava no Brasil: a história do levante dos Malês em 1835, Edição Revista e Ampliada, São Paulo, Companhia das Letras, 2003, p. 473.
} 
e teve sua pena "reformada" para quatro anos de prisão com trabalho, mais 12,5\% de multa do valor total do roubo. Tiburcio foi enquadrado no artigo 269 do Código Criminal, que dizia o seguinte: "Roubar, isto é furtar fazendo violência á pessoa ou ás cousas." Sua condenação foi equivalente ao grau médio. ${ }^{59}$

Não eram raros os casos de pessoas negras, livres ou libertas, que eram confundidas pela polícia como sendo escravas. Principalmente quando cometiam algum delito. Numa sociedade escravista, como foi a da Bahia, o escravo fugido representava prejuízo para o senhor que, na maioria das vezes, oferecia recompensa para quem o devolvesse. Como Tiburcio, muitas pessoas livres podem ter sido sentenciadas com penas previstas para escravizados. A pena de açoite, muitas vezes, era seguida do uso de ferros no pescoço por um determinado período, como foi o caso da primeira sentença da qual Tiburcio conseguiu se livrar. João Reis levantou várias condenações de pena de açoite, seguida do uso de ferros, entre os acusados de participarem na rebelião de 1835. Entre elas estava o caso do escravo de José Monteiro, que depois de ser açoitado mil vezes foi condenado a usar ferros durante o tempo em que permanecesse morando na província. ${ }^{60} \mathrm{O}$ caso de Tiburcio mais uma vez nos chama a atenção para a dualidade da legislação criminal. Como vimos, tratava-se do mesmo homem e do mesmo crime e, no entanto, sua sentença foi mudada com base no seu estatuto legal.

O quesito "qualidade" da guia de presos contempla a cor da pele ou a origem do preso. Dos 111 presos, 76 foram "qualificados". Os pardos, em número de 38, seguidos dos crioulos, em número de 19, foram as "qualificações" mais comuns. Em seguida aparecem dez brancos, dois cabras, dois pardos escuros, três índios, um preto e um negro. ${ }^{61}$ A qualificação parda indicava a cor da pela mais clara do mestiço. A crioula era aplicada ao negro nascido no Brasil. Quanto à designação branca poderia estar indicando o branco estrangeiro ou o branco brasileiro. Não localizei registros de estrangeiros brancos, na CPCT, no período em questão. Diferente do termo pardo que, às vezes, vinha acompanhado de pardo livre ou pardo forro, o branco não trazia essa referência, pois o termo branco, por si só,

\footnotetext{
${ }^{59}$ Guias de transferência de presos da cadeia da correção para a CPCT, (28/12/1865); Filgueiras Junior, Código Criminal do Império do Brazil Annotado, pp. 293-294.

${ }^{60}$ Reis, Rebelião escrava no Brasil: a história do levante dos Malês em 1835, Edição Revista e Ampliada, São Paulo, Companhia das Letras, 2003, p. 473.

${ }^{61}$ Guias de transferência de preso; "Cento e setenta e dois presos que se achão actualmente recolhidos nesta Casa"; "Relação de presos da cadeia da correção".
} 
já indicava a condição de livre. ${ }^{62}$ Quanto ao termo cabra, significava o mestiço de crioulo com o mulato ou pardo. O termo preto era quase sempre indicativo de africano de condição escrava ou forra, como vimos no caso de Adrião Bornú, que era africano e foi qualificado como preto.

Em um único caso o preso foi qualificado como negro. Para o período em questão, Hebe Mattos sugere que o termo negro tinha o mesmo significado de preto, ou seja, uma indicação à condição do escravo ou de forro. A qualificação de negro assumiria uma conotação racial somente nas últimas décadas do século XIX. Nos processos cíveis e criminais, analisados por Mattos, somente uma testemunha recebeu a qualificação de negra e sem a indicação do estatuto legal. Ao analisar tal processo, a autora constatou que se tratava de uma pessoa liberta. ${ }^{63}$ Em nosso caso, o preso que foi qualificado como negro também não teve o seu estatuto legal declarado. Seu nome era Manuel Feliciano de Andrade, 46 anos, casado, que vivia de negócios, natural de Nazareth e sentenciado por crime de morte a 12 anos de prisão com trabalho, comutada depois para 14 anos de prisão simples. Manuel não era escravo, talvez fosse liberto, pois, como já vimos, a pena de prisão com trabalho não podia ser aplicada a pessoas escravizadas.

Quanto aos qualificados como índios, eram três. Um deles foi Antonio Joaquim da Silva, julgado pelo júri de Ilhéus, provável local onde teria cometido o homicídio de que foi acusado. Antonio foi condenado a 12 anos de prisão com trabalho e, em 1855, estava a cumprir pena na Cadeia do Barbalho, quando foi removido para a CPCT em 14 de novembro de 1861. Em 1862, o administrador da CPCT queixou-se ao chefe de polícia que Antonio tinha um "mau comportamento". Em 1865, ele foi internado duas vezes no Hospital da Caridade, a primeira por estar com desinteira e a outra por dores de cabeça. ${ }^{64} \mathrm{~A}$ remoção para o hospital, muitas vezes, era o caminho que os presos utilizavam para fugir. São inúmeros os ofícios que demonstram a preocupação das autoridades com essas ocorrências. Por exemplo, a autorização de internamento do preso Manuel Marinho Pires com a qual o chefe de polícia mandava o administrador da CPCT escoltá-lo "com todas

\footnotetext{
${ }^{62}$ Ibid., p. 94.

${ }^{63}$ Hebe Maria Mattos, Das cores o silêncio: os significados da liberdade no sudeste escravista, Brasil século XIX, Rio de Janeiro, Nova Fronteira, 1998, p. 30.

${ }^{64}$ Chefe de polícia para o administrador da CPCT, (07/03/1865) e Irmã superiora para o administrador da CPCT, (03/10/1865), APEBa, Polícia, Casa de Prisão, 1865, maço 5926.
} 
as cautellas e segurança" e que deixasse ciente os médicos "de que há suspeitas que o dito preso a pretexto de molestia procura occasião de evadir-se". ${ }^{65}$

Passemos agora a analisar quais as sentenças aplicadas ao grupo e sua condição jurídica. A pena de prisão com trabalho foi aplicada em 63 presos, dos quais cinco eram livres, quatro libertos, enquanto 54 não trazem essa informação, contudo sabemos de antemão que não se tratavam de escravos, pois a pena com trabalho só cabia a livres e libertos. A pena de prisão simples consta em 12 casos e todos eles não informam a condição jurídica do preso. Os cinco casos de galés perpétuas também não informam a condição legal. Já, os seis casos de prisão perpétua estão divididos entre um de condição livre, dois escravos e um que não possui essa informação. Os dois casos de pena de morte se referem a dois escravos. E, finalmente, um preso condenado á pena de galés cuja condição legal não foi destacada. Em 22 casos não localizei quais as sentenças aplicadas. ${ }^{66}$ Observamos que a maioria dos presos, ou $56,8 \%$, foi sentenciada à pena de prisão com trabalho, o que significa dizer que nesse grupo não havia escravos, pois, como já vimos esse tipo pena só era aplicada a pessoas livres e libertas. Geralmente, quando o preso era de condição livre ele não tinha sua condição legal informada, o que pode justificar o fato de que no grupo analisado apenas 16 tiveram essa informação contemplada, seis escravos, quatro libertos e seis livres. ${ }^{67}$

Dentre os sentenciados à prisão com trabalho estava o "pardo escuro" Pedro Luis do Nascimento, casado, com 50 anos, natural de Sant'Anna do Catu e trabalhador na lavoura. Em 18 de novembro de 1861, ele foi removido da Casa de Correção para a Cadeia do Barbalho, onde ficou aguardando julgamento. Em 31 de julho de 1862, foi remetido para responder ao júri na vila de São Francisco. Lá permaneceu aguardando julgamento durante um ano. Finalmente, em 9 de julho de 1863, foi condenado a seis anos de prisão com trabalho por crime de morte. Retornou para a cadeia do Barbalho em 25 de novembro, de onde foi remetido para a CPCT. Pedro também teve sua passagem registrada no Hospital da Caridade, no dia 26 de junho de 1865, quando se recusou a extrair um dente cariado.

\footnotetext{
${ }^{65}$ Chefe de Polícia João Antonio de Araujo Freitas Henriques para o Administrador da CPCT, (24/04/1862), APEBa, Polícia, Correspondência expedida, 1861-1862, maço 5925.

${ }^{66}$ Guias de transferência de presos para a CPCT; "Cento e setenta e dois presos que se achão actualmente recolhidos nesta Casa"; "Relação de presos da Casa de Correção".

${ }^{67}$ Ibid.
} 
Em 13 de agosto, novamente, foi mandado para o hospital por causa do dente. Essa foi à última notícia que tive de Pedro.

Muitos presos, como Pedro, eram oriundos de outras cidades e vilas da província. O preso respondia ao júri no local onde o crime fora cometido. Dos 111 presos, 77 tiveram registrados os locais da suas sentenças. Desse total, vinte foram julgados na capital, 22 em cidades do Recôncavo, 19 no sertão e 16 no litoral. A penitenciária recebia presos de toda parte da província. O que também explica a origem diversificada desses presos é o Artigo 48 do Código Criminal, que determinava que o réu cumprisse suas penas "nas prisões públicas que offerecerem maior comodidade e segurança e na maior proximidade que fôr possível dos lugares dos delictos". ${ }^{68}$ Isso também explica a grande quantidade de presos, provenientes de outras localidades, em todas as cadeias de Salvador. No caso específico da pena de prisão com trabalho, a exigência da Lei se tornou mais rígida com o artigo 411 do Regulamento 120 de 31 de janeiro de 1842 que obrigava o juiz a mandar o preso para a cidade mais próxima, dentro da província, onde houvesse uma penitenciária. ${ }^{69}$

Quanto aos dois casos de pena de morte, um se refere a Anselmo, africano nagô, 40 anos, solteiro, roceiro e escravo do Barão de Cotegipe. Anselmo foi acusado de matar o administrador do engenho Cabaxi, de propriedade do seu senhor, localizado em São Francisco do Conde, onde foi condenado à pena morte em 9 de março de 1866 e mandado para a Cadeia de Correção. Dois meses depois, foi transferido para a CPCT, sob o pretexto de "ser guardado nas prisões desta capital por falta de segurança na cadeia desta vila até decisão de sua petição de graça ao poder moderador". O outro caso de pena de morte foi o de Luiza Angola, escrava de Anna Francisca Dourado, acusada de cometer crime de morte. Luiza se encontrava no Aljube e foi removida para a Cadeia da Correção, provavelmente devido à desativação daquela cadeia. Em 25 de março de 1865, seguiu para a CPCT. A maioria dos pedidos de graça era concedido pelo Imperador, despertando a insegurança da classe senhorial, que via na pena de galés perpétua - pena pela qual era comutada a de morte em caso de perdão do Imperador - um meio

\footnotetext{
${ }^{68}$ Figueiras Junior, Codigo Criminal, p. 34.

69 “incube ao juiz executor, não havendo no municipio estabelecimento proprio para a prisão com trabalho, remetter o réo ao juiz municipal do termo mais vizinho ou mais facil. que tenha tal estabelecimento. afim de ser ahi cumprida a pena; e sómente quando não seja possivel essas remessa, deverá o mesmo juiz executor proceder á substituição da penas de prisão com trabalho pela de prisão simples com o augmento da sexta parte, na conformidade do citado art. 49 do Cod. Crim., Ibid., p. 37. (nota).
} 
de o escravo se safar do domínio do senhor. Além do mais, no caso do Imperador perdoar o restante de uma prisão perpétua, o que era comum numa primeira condenação a galés, o escravo não era restituído à escravidão. ${ }^{70}$

Curiosamente não existe nenhum caso de pena de açoite no grupo analisado. Essa informação é mais uma evidência de que as autoridades, representadas principalmente pela figura do chefe de polícia, poderiam estar preservando a característica penitenciária da CPCT. Entretanto, o grupo apresenta alguns casos de penas de prisão perpétua, galés perpétua e de morte. Essas sentenças pressupõem a incorrigibilidade do preso, portanto são contrárias às ideias de recuperação do condenado, tão defendida pelas doutrinas penitenciárias. De qualquer forma, a inexistência de calabouços, ou celas para escravos, na CPCT, confirma sua peculiaridade em relação às penitenciárias de São Paulo e Rio de Janeiro. Nessas, por exemplo, os escravos integravam o quadro prisional e também cumpriam penas de açoite.

Para São Paulo, Fernando Salla demonstrou que práticas avessas às ideias penitenciárias eram usuais na Casa de Correção daquela província. Segundo o autor, "ao lado dos sentenciados [...] eram sistematicamente para ali recolhidos os escravos e os africanos "livres", que ficavam no calabouço". ${ }^{71} \mathrm{Na}$ Corte, a situação não parecia diferente. Segundo Holloway, em 1837, o calabouço, utilizado para os escravos, foi transferido para as dependências do terreno onde estava sendo construída a Casa de Correção. A intenção das autoridades era aproveitar a mão de obra dos cativos na construção da penitenciária. Mesmo com a inauguração da Casa de Correção, em 1850, o calabouço continuou a ser utilizado. Gláucia Pessoa destacou que os diretores que passaram pela administração da Casa de Correção da Corte reivindicavam, constantemente, às autoridades que o calabouço fosse transferido dali, "alegando que a aplicação de castigos correcionais aos escravos não era uma atribuição compatível, com a finalidade de uma casa penitenciária". ${ }^{72}$

Não estou com isso a dizer que na Bahia os escravos eram açoitados em menor escala do que nas outras províncias. O que pretendo destacar é que os castigos

\footnotetext{
${ }^{70}$ Sidney Chalhoub, Visões da Liberdade: uma história das últimas décadas da escravidão na Corte, São Paulo, Companhia das Letras, 1990, pp. 177-179.

${ }^{71}$ Fernando Salla, As prisões de São Paulo: 1822-1940, São Paulo, Anablume, 1999, p. 91.

${ }^{72}$ Gláucia Tomaz de Aquino Pessoa, Trabalho e resistência na penitenciária da Corte, 1850-1876, Dissertação de Mestrado, Universidade Federal Fluminense, 2000, p. 123.
} 
corporais não ocorriam na CPCT, e sim nas cadeias da cidade. Em Salvador, os escravos detidos eram mandados para as cadeias do Aljube, Barbalho e Correção. A partir do ano de 1861, quando o Aljube foi desativado, o movimento de escravos na Correção aumentou consideravelmente e depois de 1864, com a desativação da cadeia do Barbalho, esse tipo de castigo ficou, praticamente, centralizado na Correção. Nos despachos do chefe de polícia, as ordens de execução de castigos aos escravos eram direcionadas aos carcereiros das cadeias da cidade. Por exemplo, o africano João, preso na Cadeia da Correção, foi transferido a mando do chefe de polícia para o Barbalho, onde o infeliz seria castigado com cinquenta açoites, conforme havia requerido o seu senhor. ${ }^{73}$ Há ainda o caso do crioulo Luiz, preso na Cadeia da Correção, que seria castigado com "tres dusias de palmatoadas", para depois ser devolvido ao seu senhor, conforme também ordenou o chefe de polícia. ${ }^{74}$ Os escravos Elesbão, João e Delfina, detidos na casa do candomblezeiro Domingos Sodré, em julho de 1862, foram levados para a Casa de Correção onde foram castigados com palmatoadas. ${ }^{75}$ Não encontrei ocorrências como estas na CPCT.

Dos 111 prisioneiros da nossa amostragem, apenas os homens, em número de 64, tiveram o estado civil declarado. Os casados eram 27, os solteiros 29 e os viúvos em número de oito. Como podemos observar, havia um equilíbrio entre os solteiros e casados. A princípio esse dado contraria os números da população que era composta de $87,15 \%$ de pessoas solteiras, entre livres e escravas, de acordo com o censo de $1855 .{ }^{76}$ Diverge também do perfil dos prisioneiros da penitenciária da Corte que, em 1855, os solteiros representavam 77\%, seguidos de $19 \%$ de casados e $3 \%$ de viúvos. ${ }^{77}$ Pelo menos entre os presos da CPCT ter ou não família constituída não influiu na hora de cometer o crime que, em sua maioria, foi de homicídio. Essa proporção se inverte nos delitos menos graves levantados por Walter Fraga, em que 87,9\% dos presos estudados eram solteiros, acompanhando

\footnotetext{
${ }^{73}$ Chefe de polícia para o carcereiro da cadeia da correção, APEBa, Polícia, Correspondência, 18611862, maço 5745, (05/11/1861).

${ }^{74}$ Chefe de Polícia para o carcereiro da cadeia da correção, APEBa, Polícia, Correspondência, 18611862, maço 5745 (19/11/1861).

${ }^{75}$ João José Reis, Domingos Pereira Sodré: um sacerdote africano: escravidão, liberdade e candomblé na Bahia do século XIX, São Paulo, Companhia das Letras, 2008, p. 160.

${ }^{76}$ Nascimento, Dez Freguesias da Cidade de Salvador, p. 114.

${ }_{77}$ Pessoa, Gláucia Tomaz de Aquino Pessoa, Trabalho e resistência na penitenciária da Corte, 18501876, Dissertação de Mestrado, Universidade Federal Fluminense, 2000, p.189.
} 
assim a estimativa do censo de $1855 .^{78}$ Muitas vezes o preso se dizia casado pelo fato de viver com uma companheira sem, necessariamente, ter recebido os sacramentos religiosos. Outra questão que se deve considerar é que, ao dizer que era casado o preso podia garantir mais confiança por parte da polícia. ${ }^{79}$

Em 58 casos foram declaradas as variáveis estado civil e "qualidade" (cor/ origem), ampliando um pouco mais a nossa visão. Entre 28 pardos temos 11 casados, 15 solteiros e apenas dois viúvos. Dos 14 crioulos cinco eram casados, oito solteiros e um viúvo. Entre os oito brancos contemplados com essas variáveis, três eram casados, dois solteiros e três viúvos. Os dois índios que tiveram seu estado civil declarado, um era casado e o outro solteiro. Os presos declarados como preto e negro eram casados e os dois pardos escuros um casado e outro solteiro. Por fim, dois cabras, um casado e outro solteiro. Esses resultados revelam um equilíbrio entre a cor e o estado civil dos presos, o que divergia da regra da população, pois, segundo o censo de 1855, pardos, crioulos, cabras e pretos casados correspondiam a apenas $2,49 \%$ da população. ${ }^{80}$ Infelizmente, além de Eloy, não foi possível levantar fragmentos de histórias de outros presos relativas à condição civil.

Quanto à profissão, pode-se observar uma grande diversidade. Contudo, não devemos ignorar que muitos presos poderiam declarar ter um ofício apenas para não correrem o risco de serem vistos pela polícia, como desocupados. Dos 55 casos em que a ocupação foi informada, dez trabalhavam na lavoura, 15 roceiros, três alfaiates, três carapinas, três ferreiros, três negociantes, dois sapateiros, três pedreiros, cinco foram declarados "sem profissão" e os oito restantes foram registrados como charuteiro, mestre de açúcar, oleiro, ourives, professor público, servente, vaqueiro e um que declarou ter duas profissões, vaqueiro e aprendiz de alfaiate. Os presos declarados como trabalhadores da lavoura e roceiros, provavelmente, ofereciam seus serviços aos engenhos da região. Segundo Walter Fraga, o trabalho da lavoura, normalmente, era desempenhado por escravos pois as pessoas livres, na maioria das vezes, recusavam-se a executá-lo. Mas na época

\footnotetext{
${ }^{78}$ Walter Fraga Filho, Mendigos, moleques e vadios na Bahia do século XIX, Salvador, EDUFBA, 1999 , p. 82.

${ }^{79}$ Ibid.

${ }^{80}$ Nascimento, Dez Freguesias da Cidade de Salvador, p.114.
} 
das secas era comum que elas oferecessem sua mão-de-obra aos engenhos, como meio de sobrevivência. ${ }^{81}$

Dentre os presos ocupados na lavoura estavam dois brancos. Um deles era Ponciano de Almeida Campos, 30 anos, solteiro, condenado pelo júri de Cachoeira à pena de quatro anos e meio de prisão com trabalho, mais multa relativa a metade do tempo, e foi remetido para a CPCT em 14 de julho de 1864 . O outro era João Pereira da Costa, 42 anos, casado, condenado pelo júri da capital, em 1860, pelo crime de estelionato. Foi mandado para a Cadeia de Correção e remetido para a CPCT em 1864. Não localizei qual foi a sua sentença. ${ }^{82}$

O ofício de professor público era a ocupação de Francisco Ribeiro de Seixas, branco, livre, casado, 24 anos e natural da Bahia. ${ }^{83}$ Francisco foi descrito como sendo "baixo, corpo regular, rosto comprido, olhos castanhos, nariz afilado, boca pequena, labios regulares, dentes perfeitos, barba pouca". Ele foi preso na capital, acusado da morte de Florinda Serafina de Noronha Gomes. Foi remetido para Camamu, em 18 de abril de 1863, para responder ao júri, o que não aconteceu devido ao "seu estado de loucura". No mês seguinte retornou para a capital e, em 18 de fevereiro de 1865, seguiu novamente para Camamu, onde desta vez respondeu ao júri que o sentenciou a dezoito anos de prisão com trabalho, mais um ano de prisão simples. ${ }^{84}$ É provável que, da primeira vez, Francisco tenha se passado por louco para tentar fugir da condenação, ou, se estava mesmo doente, deve ter ficado aqueles dois anos, ou na Casa de Correção, junto com outros tidos como loucos, ou na enfermaria de alienados do Hospital da Caridade. A cidade de Salvador viria a ter uma instituição destinada aos doentes mentais somente em 1874, quando foi inaugurado o Asilo São João de Deus. ${ }^{85}$

\footnotetext{
${ }^{81}$ Walter Fraga Filho, "Encruzilhadas da liberdade: histórias e trajetórias de escravos e libertos na Bahia”, 1870-1910, Tese de Doutorado em História, UNICAMP, 2004, pp. 29-31.

${ }^{82}$ Guia de transferência da cadeia da correção para a CPCT, APEBa, Casa de Prisão, 1861-1886, maços 5942; APEBa, "Cento e setenta e dois presos que se achão actualmente recolhidos nesta Casa", Conforme já mencionado, o preso respondia ao júri na mesma localidade onde cometia o crime.

${ }^{83}$ Atualmente estou desenvolvendo um trabalho específico sobre esse personagem.

${ }^{84}$ Guia de transferência de Francisco Ribeiro de Seixas para a CPCT, APEBa, Casa de Prisão, 18611886, maço 5942.

${ }^{85}$ Sobre o Asilo São João de Deus e a loucura na cidade de Salvador, ver: Venétia Durando Braga Rios, “O Asylo de São João de Deus: as faces da loucura”, Tese de Doutorado, Pontifícia Universidade Católica de São Paulo, 2006.
} 
Dentre os ofícios dos presos, alguns eram mais especializados do que outros como, por exemplo, o de ourives, que era considerado um artesão refinado. Diferente do ferreiro e do funileiro que, apesar de trabalharem com metal, não possuíam o mesmo prestígio daquele que fabricava joias de ouro e de prata. ${ }^{86} \mathrm{O}$ preso que teve sua profissão declarada como ourives foi o crioulo livre Eloy da Cruz Lacerda de 26 anos, removido da Cadeia do Barbalho para a CPCT, em 4 de fevereiro de 1862. ${ }^{87}$ Eloy foi condenado em 1856, acusado de roubar uma joalheria, vizinha de sua casa, localizada na Rua dos Ourives, loja sete. Eloy vivia com sua companheira, a crioula Cecília Maria da Conceição, no segundo andar do prédio de número nove da mesma rua. Há cerca de um mês o casal havia se mudado para lá. A loja foi arrombada no dia vinte de junho de 1855 e, no dia seguinte, Eloy foi preso em flagrante enquanto vendia três colares de ouro a um cambista, na movimentada Freguesia da Conceição da Praia. Eloy foi levado para a cadeia do Aljube. ${ }^{88}$

$\mathrm{Na}$ época do crime, Eloy tinha apenas 19 anos. Então, seu pai, Athanazio da Cruz Lacerda, recorreu da sentença declarando que o filho era "menor e idiota", em função de uma queda que o mesmo havia tomado "em tenra idade", época em que morava em Santo Amaro. Conforme o pai, o menino caíra de um carro e, como consequência da queda, que "lhe partindo um órgão o foi deteriorando absolutamente". Tal acidente teria lhe trazido consequências que implicaram em seu aprendizado do Francês e de Mecânica. Ainda segundo o pai, Eloy teria concluído o aprendizado das primeiras letras e do ofício de ourives antes do trágico acidente. O pai apercebeu-se que "algum desarranjo mental o afligia" diante do que "praticava na própria casa, já pelo que fazia fora dela". Chegando Eloy, à idade adulta, tornou-se difícil para seu pai o controle dos seus comportamentos, deixando este a casa paterna e passando a viver em casas alheias ou algumas alugadas mas sempre sustentado pelo pai. ${ }^{89}$

No seu primeiro interrogatório, em 1855, Eloy não pareceu ter problemas mentais. Em 29 de julho de 1856, após a apelação da sentença, Eloy teve um segundo julgamento e, nessa ocasião, ele tentou convencer, inutilmente, ao juiz

${ }^{86}$ Alfredo Eurico Rodrigues Matta, "Casa Pia Colégio de Órfãos de São Joaquim: de recolhido a assalariado”, Dissertação de Mestrado, Universidade Federal da Bahia, 1996, p. 171.

${ }^{87}$ Guia de transferência de Eloy da Cruz Lacerda para a CPCT, APEBa, Casa de Prisão, 1861-1886, maço 5942 .

88 "Processo Crime de Eloy da Cruz Lacerda", APEBa, Judiciária, 22 / 758/02.

${ }^{89}$ Petição do pai de Eloy, “Processo Crime de Eloy da Cruz Lacerda”, APEBa, Judiciária, 03/75 /05. 
da sua suposta "idiotice". Sua condenação foi de quatro anos de prisão com trabalho e multa de $5 \%$ do valor furtado, mas esse valor foi comutado para dois anos e quatro meses de prisão simples, acrescidos ao tempo da pena com trabalho. ${ }^{90}$ Logo após o julgamento, Eloy foi transferido do Aljube para a cadeia da Correção. Em 1860, seguiu para a cadeia do Barbalho, onde ficou preso até 1862 quando foi remetido para a penitenciária. Eloy foi mais um daqueles que viveram no período da transição da reforma prisional, além de também ter sido mais um a romper com o silêncio da documentação oficial, no que diz respeito à visão do preso. Michelle Perrot apontou o analfabetismo como uma das muralhas que rodeavam os prisioneiros, impedindo-os assim de quebrar o silêncio. ${ }^{91} \mathrm{O}$ que não quer dizer que os iletrados não buscassem seus procuradores para escrever por eles. Eloy rompeu essa barreira, pois havia aprendido "as primeiras letras", além de ter também sabido transitar na comunidade prisional, principalmente no que diz respeito a sua relação com os funcionários.

Em 1859, quando estava ainda na cadeia da Correção, escreveu a seguinte correspondência para o chefe de polícia:

Eloy da Cruz Lacerda prezo nas Cadeias da casa de Correção, que acabou de cumprir sua sentença, faltando-lhe ainda o tempo correspondente á multa, vem rogar á V.Sas. que á bem de sua saude bastante alterada, como bem o podera ver o Medico da Camara, se V.Sa. assim o determinar, o mande mudar da prizão, onde se acha actualmente para em que se achão os presos Aprigio Joaq[ui]m do Amparo, Marcos Borges Ferraz, João Alves Portella Bugarim, que além de mais espaçosa e clara encerra menos prezos, do que a em que se acha o supplicante. ${ }^{92}$

Eloy estava pleiteando uma mudança de cela, além de lembrar ao chefe de polícia que sua pena principal havia sido cumprida, precavendo-se de um possível esquecimento da justiça. A cadeia da Correção era dividida em 12 celas, nas quais eram distribuídos os sentenciados, não sentenciados, mulheres, pronunciados etc. Naturalmente, deveriam existir algumas celas melhores que outras.

\footnotetext{
${ }^{90} \mathrm{~A}$ informação de prisão simples consta em uma petição redigida pelo próprio Eloy em julho de 1862. Petição de Eloy da Cruz Lacerda para o presidente da província, (jul./1862), APEBa, Casa de Prisão, 1836-1868, maço 3082.

${ }^{91}$ Michelle Perrot, Os Excluídos da História: operários, mulheres e prisioneiros, São Paulo: Paz e Terra, 2001, p. 238.

${ }^{92}$ Petição de Eloy da Cruz Lacerda para o chefe de polícia. Naquela época, as celas de uma cadeia também eram chamadas de prisão.
} 
O carcereiro informou que a cela pleiteada por Eloy era "um quarto aberto, que ainda assim, não oferece facilidade de comunicação com a rua", e que o preso não poderia se aproximar do portão sem atravessar o pátio e assim ser visto pelo "Comandante da Guarda, o cabo ou as sentinelas". O médico da Câmara constatou sua doença e disse que ele necessitava de "uma boa higiene e uma prisão em que o ar gere livre". ${ }^{93}$ Com isso, no dia 30 de agosto de 1859, o chefe de polícia deferiu o pedido de Eloy.

Em 1860, Eloy foi transferido para a cadeia do Barbalho. Em outubro desse ano, alguns dias antes da inauguração da penitenciária, Eloy escreveu outra petição ao chefe de polícia tentando não ser transferido com outros companheiros para a nova instituição.

Eloy da Cruz Lacerda preso nas cadeias do Barbalho a bem do seu direito precisa que V.S $S^{a}$ mande que o actual Carcereiro lhe sertifique se é ou não verdade que o digno anteceçor de V.Sa mandou por uma Portaria que o actual Carcereiro fizesse a lista dos Presos sentenciado que tinhão de ser removido p[ara] a Cadêia do Engenho da Conceição e ecpttuando (sic) ao dicto Supplicante visto os seus sufrimentos e por estar concluindo vinte oito meses de Prisão simples de seo tempo, falta-lhe nove meses para o que digo dezenove meses. ${ }^{94}$

Eloy conseguiu adiar a sua remoção até fevereiro de 1862, quando seguiu para a CPCT. Na petição de Eloy, nota-se que ele estava ciente do seu tempo de pena, assim como informado daquilo que se passava na repartição de polícia, pois tinha conhecimento da Portaria que autorizava a transferência dos presos que iriam inaugurar a nova penitenciária. O carcereiro Antonio Pereira de Almeida confirmou que, de fato, existia uma Portaria de 30 de outubro de 1861, que tratava da transferência de presos para a penitenciária, onde o chefe de polícia ordenava ao carcereiro "que organizasse uma relação e entregasse ao administrador da Casa de Prisão com Trabalho, ecceptuando á Eloy da Cruz Lacerda, de todos os réos condennados que aqui se achavão recolhidos, com todos os esclarecimentos concernentes a cada um deles". ${ }^{95}$

Eloy foi atendido e não foi transferido para a penitenciária. A sua remoção para a CPCT só ocorreu no dia 5 de janeiro de 1862, mas não significou o fim

${ }^{93}$ Petição de Eloy da Cruz Lacerda para o chefe de polícia.

${ }^{94}$ Petição de Eloy da Cruz Lacerda para o chefe de polícia, APEBa, Casa de Prisão, 1836-1888, maço 3082 .

${ }^{95}$ Ibid., verso. 
de sua luta.${ }^{96}$ Em julho do mesmo ano ele escreveu outra petição, desta vez endereçada ao presidente da província. Com precisão ele informava que, em 24 de março de 1861, sua pena de quatro anos de prisão com trabalho havia terminado, passando, a partir de então, a contar a parte adicional de sua pena, referente a dois anos e quatro meses de prisão simples, por acreditar ter, assim, adquirido o direito de ser transferido para uma cadeia comum. ${ }^{97}$ Ele pedia sua remoção para a Cadeia do Barbalho ou da Correção, utilizando como mais um argumento a falta de condição higiênica da penitenciária que, segundo ele, estaria fazendo piorar o seu estado de saúde. Eloy tentou sensibilizar o presidente da província o qual despachou para o chefe de polícia resolver a questão. Dessa vez seu pedido foi indeferido e Eloy terminou por cumprir sua pena na penitenciária, onde se encontrava. A permanência de Eloy na prisão, não excedeu nem um dia a mais do que tinha sido estipulado pela justiça. Ele foi solto em 25 de julho de 1863, data exata do final da sua sentença. Sem dúvida que essa precisão do aparelho judiciário estava diretamente relacionada a uma luta, incansável, por seus direitos, demonstrando o seu conhecimento do que a justiça podia exigir dele.

\section{Considerações finais}

Eloy se destacou entre os 111 presos pelas possibilidades da documentação desse grupo. Quero dizer com isso que a documentação mais geral apresenta muitos presos em situações semelhantes. As correspondências individuais e coletivas de presos, endereçada às autoridades provinciais, eram os meios mais utilizados para protestar contra o regime prisional. ${ }^{98}$ Trata-se de uma documentação que auxilia o pesquisador a penetrar numa visão de mundo que, por muito tempo, foi negligenciada pela historiografia. Felizmente nas últimas décadas esse quadro tem mudado e, cada vez mais, o estudo da prisão, partindo do ponto de vista do preso, tem sido valorizado. Outra questão importante sobre o perfil do grupo estudado é que a sua maioria já cumpria pena nas cadeias da cidade e, ao

\footnotetext{
${ }^{96}$ Petição de Eloy para o presidente da província.

${ }^{97}$ Ibid.

${ }^{98}$ Sobre correspondências de presos, ver Carlos Aguirre, "Disputed Views of Incarceration in Lima, 1890-1930: The Prisoners' Agenda for Prison Reform, In: Ricardo Salvatore, Carlos Aguirre e Gilbert M. Joseph (orgs.), Crime and Punishment in Latin America: Law and society since late colonial times, London, Duke University, 2001, pp. 342-367.
} 
seguirem para a penitenciária, levaram com eles suas vivências prisionais que, sem dúvida, devem ter influenciado no funcionamento da nova instituição e na construção de uma sociedade prisional que, provavelmente, contribuiu para a formação de um modelo baiano de sistema penitenciário. 